\title{
OBITUARY
}

\section{ALFRED GUILLAUME}

For a wide circle of his friends the death of Alfred Guillaume on 30 November 1965 , shortly after his 77 th birthday, was a sudden shock, though not altogether unexpected within his family. To the last months he was sending offprints of essays and notes on the interpretation of difficult passages in the Old Testament to friends who marvelled at his undiminished vigour of mind. Throughout his active years, when administrative duties occupied a great part of his time, he had always pursued his research in his chosen field, bordering on both Arabic and Hebrew studies.

Tall and muscular, Guillaume was of Channel Island stock settled in England, and never lost his fondness for the countryside and the tending of a garden. In his later life he enjoyed watching the games he had once played on the odd day he could spare at Twickenham or Lords. Above all a man of humour with an infectious laugh, he could remove dyspeptic gloom and induce a balanced view of difficulties; impatient of real negligence of duty or bad behaviour, he did not allow a passing phase to prejudice him long. Loved by his family, continuously bound to many colleagues, Alfred Guillaume leaves a happy memory among his circle.

He went up to Oxford a year or two later than the normal, to Wadham, with an Exhibition and then the Pusey and Ellerton Hebrew scholarship ; in 1913 he was awarded a first class in the Oriental schools-Hebrew and Arabic with Syriac as the third subject, then an exacting test for an Englishman-and won all the prizes available, the Houghton Syriac and Septuagint, and the Junior Kennicott Hebrew scholarship. Thus he was solidly based in the intense and extremely critical learning of the Oxford Semitic scholars of his time. It is probably difficult for anyone now to understand the intellectual ambience that then prevailed; over 50 years of discovery, decipherment, and minute inquiry into details have altered so much. S. R. Driver, to whom, with the Americans Brown and Briggs, all English-speaking scholars are indebted for the revision of Gesenius's dictionary, had established a form of the 'Higher Criticism' developed at Tübingen and other German and Dutch centres as academic doctrine ; the ignorance shown in counter-criticism, generally of the kind found much earlier in the attacks on Robertson Smith in Scotland, and the erratic views of Sayce, left students the more convinced that the methods and results of old Testament criticism were beyond question. In Arabic studies Wellhausen was, with Goldziher, the prevailing influence, but at Oxford the idiosyncracies of D. S. Margoliouth created an extreme scepticism. To appreciate Guillaume's stature as a scholar it is necessary to compare his work with the doctrine he received-a comparison he never made himself-for the stages by which he arrived at his final attitudes were part of his make-up; but the labour and mental effort demand a proper appreciation.

In 1914 when the first World War broke out Guillaume, already an ordinand, 


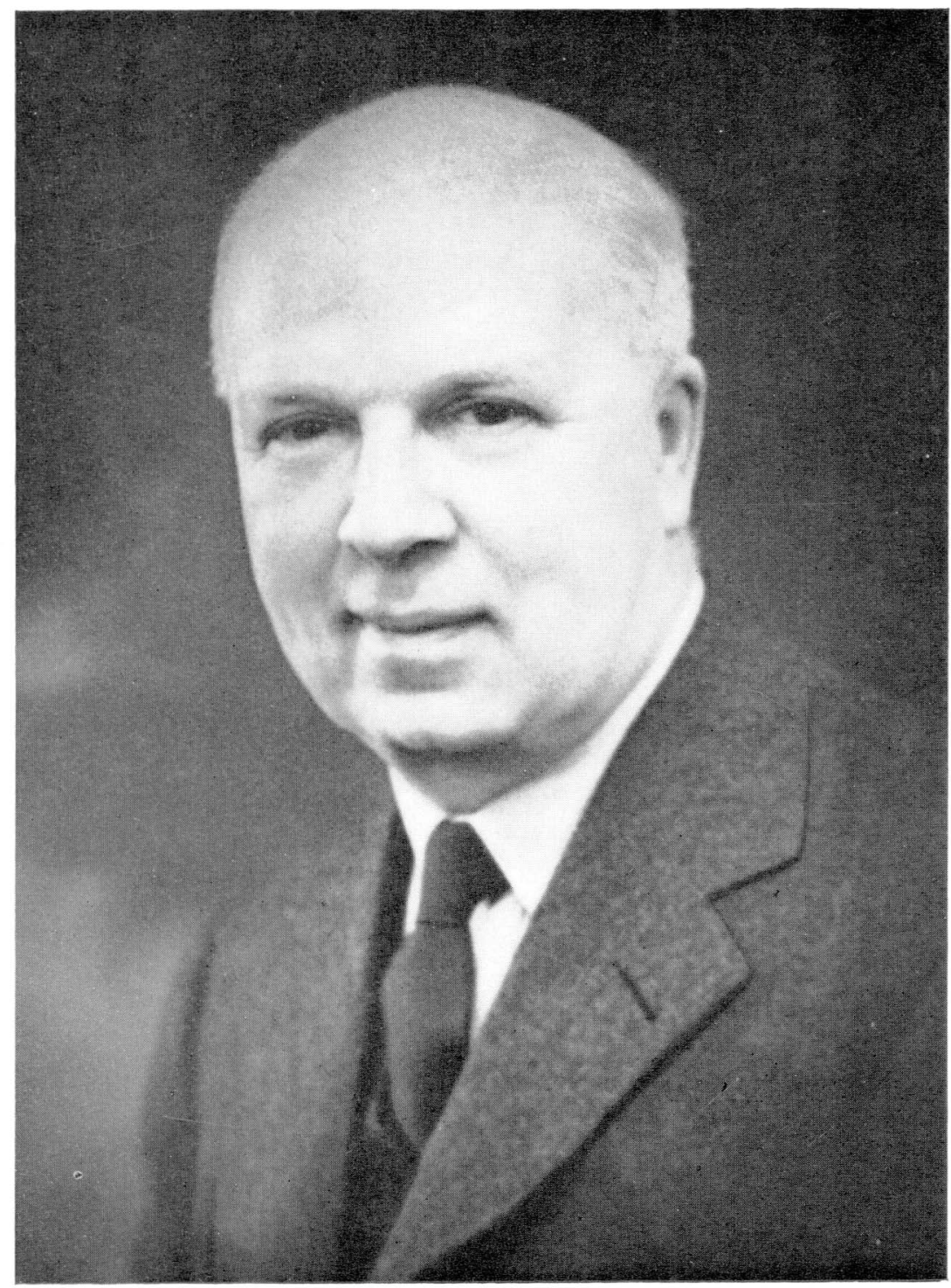

Alfred Guillaume

BSOAS, XXIX] 
joined, as many of us did, a Kitchener battalion of the Royal Fusiliers as a private, but was given a commission in the Lancashire Fusiliers (a tough lot) in 1915 and served with them in France. Sick leave in England gave time for his marriage to Miss Margaret Woodfield Leadbitter, daughter of the Rector of West Walton, Norfolk, in 1916, then he was sent to Egypt and at the end of his military service was Captain on the staff of the High Commissioner, mentioned in despatches-for some who remember the circumstances as honourable as a decoration. The ability to deliver a lecture in modern Arabic, rare at that time among European scholars, was acquired in Cairo.

He returned to Oxford in 1919 as Liddon Theological Student, took a curacy, and lectured on Hebrew to theological students at Cuddesdon College. After acting as lecturer on the Old Testament at King's College, London, he was appointed Professor of Hebrew and Oriental languages at Durham, 1920-30, serving also as a parish Rector, years of which he and his wife retained happy memories. From 1930 to 1943 he was Principal of the training college for Church of England schoolteachers at Culham, and acted as honorary Assistant Keeper of Public Records during the war years. In the winter of 1944-5 he was at the American University of Beirut as Professor of Arabic, and in the autumn succeeded S. H. Hooke, an old Oxford friend, as Davidson Professor of Old Testament Studies in the University of London. In 1947 he accepted the Arabic chair at the School.

Up to this time his main published work on the Old Testament is to be found in contributions to the New commentary on Holy Scripture, including the A pocrypha, 1928, for which he acted as co-editor with Bishop Gore, and in the Bampton Lectures, Prophecy and divination, 1938, an examination of both the passages in the OT which refer directly to omens and those which can be explained on comparative grounds as due to priestly or prophetic routine in augury. His work in Arabic studies had been devoted to the religious teaching and thinking in the early centuries of Islam in the two holy cities of the Hijaz, a subject which seems not to have interested English or Scots scholars at the end of the nineteenth century, though vigorously examined by the Germans and Dutch. The traditions of Islam, 1924, was followed by The infuence of Judaism on Islam, 1927, his thesis for D.D., and The summa philosophiae of al-Shahrastānī : Kitäb nihäyatu 'l-iqdām, 1931, from the time when he was collaborating with Sir Thomas Arnold on The legacy of Islam. The courses he gave for undergraduates between 1947 and 1955 at the School were therefore directed to instruction in the basic tenets and philosophy of Islam, and their tenor can be found, reduced to small scope, in his Penguin of 1954, Islam; it has been translated into Arabic, Italian, and Spanish, no small tribute to its authority when the available books in these languages are considered. These years also led to his translation of Ibn Ishāa as edited by Ibn Hishām, The life of Muhammad, 1955, a boon for all those of us who cannot read or cannot easily find their way about in that compilation. Because these books superficially make no claim to originality, nor any parade of argumentation about 
modern views with abundant references, it is easy to forget that they represent an almost total change of attitude from that known to Guillaume at Oxford and indeed still common in some quarters in 1940-50. Doubts dispelled by new knowledge are quietly suppressed ; legitimate scepticism is mentioned without unnecessary emphasis, but proved facts appear where relevant. Islamic religious tradition will never, probably, become a popular subject: but the study in England has been set on a new course. Guillaume was made a Member of the Arab Academy of Damascus in 1949, and of the Academy of Baghdad in 1950 ; 'ulamä' recognized in him one learned in their specific 'ilm even before the appearance of these books.

After Guillaume retired from the School in $\mathbf{1 9 5 5}$ he spent two years at Princeton as Visiting Professor, and then returned to his home near Abingdon, still busy on contributions to the Encyclopaedia of Islam and other articles. His last work on the traditions was published in 1960, New light on the life of Muhammad, a summary of the contents of a MS in a library at $\mathrm{Fez}$, about which Dr. Hopkins had sent him a brief report; Dr. Allouche obtained a microfilm for his use. This MS, lacking the title at the beginning, is an account by al-Bazzāz of a report by Yūnus ibn Bukair, who heard Ibn Isḥāq's lectures at Küfa and added some 200 had $\bar{t} t h$ from other sources. In default of the edition Guillaume had hoped to produce of this much damaged and difficult text, he gave a full summary of passages not in Ibn Hishām's edition, and an introduction providing necessary information with comments on points of special interest. It was a remarkable testimony to his eyesight and energy at the age of 72 .

For many years he had published brief notes on passages in the OT formerly subjected to radical--generally too radical-emendation. He was extremely sceptical where emendation required major alterations in the consonantal text, but welcomed with great pleasure confirmation of modern corrections in, for instance, the great Isaiah scroll from the Dead Sea region. Most of his notes justified the consonantal text by accepting the existence of a percentage of words explicable by Arabic root-significance larger than was recognized before, say, 1914, when legitimate comparisons were thought to be confined to Aramaic and-rarely-Akkadian. Freer use of Arabic for comparison developed during the 1930's and 1940's, but spasmodically, and sometimes without regard to whether the meaning assigned to the Arabic word was really ancient and primary. Results were then generally doubtful, sometimes unacceptable, and always subject to the suspicion of dictionary-flipping. Guillaume's mastery of both languages put his suggestions into a different class. Finally, this work brought before him the problems of the book of Job-form (generally dissected into two entities), background (not usually considered as belonging specifically to a particular area), date (commonly, in 'Introductions' to the OT, assigned to the Hellenistic period or not much earlier). At the time of his death he had nearly finished a book on this subject. In outline what he had to say is by now already known from essays published in the last two years, but it will be fascinating to read his full exposition when the book appears, as it surely must, even 
if the final revision is lost. On the three points Guillaume came to firm conclusions : the form corresponds to one known in Arabic literature, the background specifically the area east of Jordan, near the caravan route to Taima and the Hijaz, the date sixth century B.c., the time of Nabonidus's campaign, referred to in the text. As was usual with him, Guillaume did not in these essays enter into arguments against the orthodox critical views he had once accepted; he concentrated on the positive aspects of what he had to say. He was obviously much influenced by Professor Gadd's edition of the Nabonidus texts from Harran, yet the freshness of mind displayed astonished me. For 40 years I have been a heretic about the book of Job, as the result of conversations with Budge in the 1920's, and well laughed at by friends for believing in an early date-earlier than even Guillaume's. His last work, at the age of roughly 75 , has all the virtues that should attach to the writing of a man 40 years younger.

SIDNEY SMITH 